\title{
WAR, TYPES, AND MANDEVILLA (APOCYNACEAE): A NEW SPECIES AND THE REDISCOVERY OF A RARE SPECIES FROM BRAZIL
}

\author{
J. Francisco Morales ${ }^{1} \&$ Ludovic J. C. Kollmann ${ }^{2}$
}

\begin{abstract}
${ }^{1}$ Research Associate, Missouri Botanical Garden, 4344 Shaw Blvd., St. Louis Missouri 63110, U.S.A.; Bayreuth Center of Ecology and Environmental Research (BayCEER), University of Bayreuth, Universitätstrasse 30, 95447, Bayreuth, Germany; drjfranciscomorales@gmail.com (author for correspondence).

${ }^{2}$ Instituto Nacional da Mata Alântica, Av. José Ruschi, 4, CEP 29650-000 Santa Teresa, Espirito Santo, Brazil.
\end{abstract}

\begin{abstract}
Morales, J. F. \& L. J. C. Kollmann. 2020. War, types, and Mandevilla (Apocynaceae): a new species and the rediscovery of a rare species from Brazil. Darwiniana, nueva serie 8(2): 449-459.

The true identity of Mandevilla luetzelburgii (Apocynaceae) is clarified and the new M. bullata, largely misidentified as the former species, is described. Drawings for both species are given and a key for morphologically related species is provided. A lectotype is selected for Dipladenia luetzelburgii Ross \& Markgr. Mandevilla bullata is assessed as Endangered (EN) and M. luetzelburgii as Critically Endangered (CR), according to IUCN criteria.
\end{abstract}

Keywords. Apocynoids; Dipladenia; Espirito Santo; Inselberg; Mesechiteae.

Resumen. Morales, J. F. \& L. J. C. Kollmann. 2020. Guerra, tipos y Mandevilla (Apocynaceae): una nueva especie y redescubrimiento de una especie rara de Brasil. Darwiniana, nueva serie 8(2): 449-459.

Se clarifica la identidad de Mandevilla luetzelburgii (Apocynaceae) y se describe una nueva especie: M. bullata, erróneamente identificada como la especie anterior. Se brindan dibujos para ambas especies así como también, una clave para discriminar las especies morfológicamente relacionadas. Se selecciona un lectotipo para Dipladenia luetzelburgii Ross \& Markgr. Mandevilla bullata es categorizada como Amenazada (EN) y M. luetzelburgii como Críticamente Amenazada (CR), según los criterios de la IUCN.

Palabras clave. Apocynoides; Dipladenia; Espirito Santo; Inselberg; Mesechiteae.

\section{INTRODUCTION}

War World Two had catastrophic consequences in Europe. The botany was affected by the destruction of many types and historical collections from around the World. From the nine major herbaria in Germany, only GOET, HBG, JE, KIEL and $\mathrm{M}$ survived almost without damage, whereas the others were totally or partially destroyed (Poppendieck, 1990; acronyms after Thiers, 2020).

The Herbarium from the Berlin Botanic Garden and Botanical Museum (B) contained around
4 million specimens at the beginning of the 1940s (Eckardt, 1965) and it was one of the four largest in the world (Merrill, 1943). However, a raid bomb during March 1-2, 1943, destroyed by fire the building and hundreds of thousands of specimens, including the library (Hiepko, 1987). The destruction of the Herbarium is probably the major botanical catastrophe that occurred in the last 100 years, considering the types and historical collections destroyed. Although more than 20,000 type specimens and 400,000 sheets were saved, Apocynaceae was destroyed. 
Robert E. Woodson Jr. (1904-1963) was one the most important specialist of neotropical Apocynaceae of the $20^{\text {th }}$ century (Morales et al., 2017). He spent the summer of 1930 abroad visiting several herbaria in Europe, examining type specimens and historical collections (Allen et al., 1965). In Germany, he studied the collections at B, which was particularly rich in Apocynaceae types. Shortly after, he published several works of neotropical Apocynaceae (e.g., Woodson, 1933; 1935; 1936).

Mandevilla Lindl. (Mesechiteae) was described in 1840 based on a cultivated specimen from Argentina ( $M$. laxa Lindl.). Before Woodson's monograph (1933), it was in taxonomic chaos with its members distributed in at least ten genera (Amblyanthera Müll. Arg., Dipladenia A. DC., Echites Jacq., Eriadenia Miers, Exothostemon G. Don., Heterothrix Müll. Arg., Homaladenia Miers, Laseguea A. DC., Macrosiphonia Müll. Arg., and Micradenia Miers). Woodson (1933) proposed a new circumscription and recognized 108 species. He maintained Macrosiphonia, but its circumscription was not supported by molecular data (Simões et al., 2006). Nowadays, Mandevilla comprises around 200 species (Morales \& Morais, 2020).

Dipladenia luetzelburgii Ross \& Markgr. was described based on a specimen collected in 1917 (Lützelburg 7155, M). The type has two sheets (M cb 0210882 and M cb 0210883, both in poor condition) with detached structures (leaves, flowers, and fruits). A duplicate (with stems, leaves, flowers, fruits, and seeds) was deposited at B (F neg 4503), but it was destroyed in 1943. An additional fragmentary specimen at M (M cb 0183695) has two leaves, a node of a young branchlet, and four old intrapetiolar colleters. Line drawings from the stems (showing the developed colleters), leaves, and vascular cells of the stems and bracts are attached to the sheet. Woodson (1933) examined these duplicates (B, M), and transferred this species to Mandevilla, and provided a description.

Three specimens collected between 1964 and 1966 somewhere around Pedra Azul, state of Minas Gerais, Brazil (Duarte 9663, HB, Z; Fromm \& Trinta 1830, HB, M, NY; Trinta \& Fromm 754, CR, HB, NY, R, Z) were identified by Frederick Markgraf (Z) as M. luetzelburgii. However, these specimens differ in several morphological characters from the type of $M$. luetzelburgii (Table 1). Additional specimens collected after 1966, have been identified in Brazilian herbaria following Markgraf's determinations. In the revision of the Brazilian species of Mandevilla subgenus Mandevilla, Sales (1993) did not examine the type of M. luetzelburgii (only the Field Museum photograph). The description provided by her was based (partially) on the specimens determined by Markgraf. Recent identifications in Brazilian herbaria have followed the concept of Sales (1993).

The study of the type of Dipladenia luetzelburgii vs. the material from Brazil identified as $M$. luetzelburgii confirms that two different species have been confused. Both species are endemic to inselbergs or rocky formations. The rare $M$. luetzelburgii has been known only from the type, collected at Serra da Pindoba, Rio Doce, Espirito Santo. The exact location of this Serra remained unknown for decades, but the second author (through interviews with local people) discovered its ubication $\left(19^{\circ} 24^{\prime} 21^{\prime \prime} \mathrm{S}\right.$ $19^{\circ} 29^{\prime} 57^{\prime \prime} \mathrm{S} / 40^{\circ} 50^{\prime} 26^{\prime \prime} \mathrm{W}-40^{\circ} 53^{\prime} 13^{\prime \prime} \mathrm{W}$ ). Many inselbergs formations are found in this area (Baixo Guandu near the border of Espirito Santo and Minas Gerais), as well as around Conselheiro Pena (Minas Gerais), but the region remains unexplored.

Table 1. Differences between Mandevilla bullata and M. luetzelburgii

\begin{tabular}{|l|l|l|}
\hline \multicolumn{1}{|c|}{ Character } & \multicolumn{1}{c}{ Mandevilla bullata } & \multicolumn{1}{c}{ Mandevilla luetzelburgii } \\
\hline Leaf blade & Strongly bullate & Not bullate \\
\hline Secondary and tertiary veins & $\begin{array}{l}\text { Both conspicuously impressed on both } \\
\text { surfaces }\end{array}$ & $\begin{array}{l}\text { Secondary veins slightly impressed on both surfaces, tertiary } \\
\text { veins almost inconspicuous abaxially, inconspicuous adaxially }\end{array}$ \\
\hline Pedicels & $9-16 \mathrm{~mm}$ long & $5-8 \mathrm{~mm}$ long \\
\hline Sepals & $5.3-8 \mathrm{~mm}$ long & $4-5 \mathrm{~mm}$ long \\
\hline Diameter of the corolla mouth & $13-18 \mathrm{~mm}$ & $9-10 \mathrm{~mm}$ \\
\hline Apex of the floral bud & acuminate & acute \\
\hline Nectaries & 2 & 5 \\
\hline
\end{tabular}


Inselbergs have been identified as a hotspot of plant endemism in several countries (Porembski et al., 1994; Barthlott \& Porembski 2000; Porembski \& Barthlott, 2000), including Brazil (Porembski et al., 1998; Jacobi et al., 2007; Porembski, 2007; Ribeiro et al., 2007).

During 2018 a population (after the type locality) of $M$. luetzelburgii was found in the region of Conselheiro Pena, Minas Gerais. The morphological characters match with the type fragments at $M$ and with the photo from the destroyed duplicate at B. The study of two populations (Bahia and Espirito Santo) of the second species erroneously confused with $M$. luetzelburgii confirmed that it is an undescribed species. The review of types for a revision or monograph (even fragments) is critical. In Mandevilla, the omission of this process has led to the confusion of species (e.g., Morales, 2005). Some species (e.g., M. muellerii Woodson) are still known only from the destroyed type at B. More than 75 years after the destruction of the Berlin herbarium, the consequences still affect plant taxonomy.

A description of $M$. luetzelburgii is given, based on the type fragments and the new population found in 2018 and a lectotype is proposed. The second species confused with that taxon is described as a new species (M. bullata), increasing to 16 the number of species growing on Inselbergs in Brazil (Morales \& Kollmann 2020; Morales \& Morais 2020). Illustrations, photographs, a distribution map, and a key to separate similar species are provided. Both species were assessed according to IUCN criteria.

\section{MATERIALS AND METHODS}

Specimens and type material from the following herbaria were examined: B, BHCB, CEPEC, CR, HB, HUEFS, K, M, MBM, MBML, MO, NY, R, RB, SPF, UBT, US, WAG, and Z, acronyms cited follow Thiers (2020). Descriptions were based on herbarium specimens and fresh material. The terminology follows Radford et al. (1974). Parts of the corolla tube follow Morales \& Fuentes (2004) and Morales et al. (2020). The conservation status was assessed by calculating the extent of occurrence (EOO) and the area of occupancy (AOO) with GeoCAT (Bachman et al., 2011) and applying the IUCN Red List Categories and Criteria, version 3.1 (IUCN, 2017).
The AOO was calculated based on a user defined grid cell of $2 \mathrm{~km}$. A morphological species concept was adopted for practical delimitation, so that apparent gaps in morphological variation (especially if associated with geographical disjunction) were used to distinguish species (i.e., a phenetic species concept sensu Judd et al., 2016) (Juárez et al., 2018). Resulting species circumscriptions were compared to type specimens and to protologue descriptions to verify the proper application of names. The resulting taxon is assumed to represent independent evolutionary lineages (i.e., evolutionary or phylogenetic species definitions, sensu Judd et al., 2016).

\section{TAXONOMIC TREATMENT}

Mandevilla bullata J.F. Morales \& L. Kollmann, sp. nov. TYPE: Brazil, Minas Gerais, divisa entre municipios de Espinosa e Montezuma, a 35 km de Serra do Pau D 'Arco, 15 $5^{\circ} 04^{\prime} 55^{\prime}$ ' S 42 $38^{\prime}$ ' 27' W, 1300-1400 m a.s.1., 15-III-1994 (fl), N. Roque, C. M. Sakuragui, R. M. Harley, P. T. Sano \& V. C. Souza 15044 (holotype, $\mathrm{SP}$; isotypes CR, K [K cb 000989062, K cb 000989063]). Figs. 1 and 4 A-D.

Mandevilla bullata shows affinity to $M$. splendens (Hook.) Woodson, but it is distinguished by its sepals 5.3-8 mm (vs. 8-14 mm), upper part of the corolla tube 11-19 mm (vs. 18-28 mm), narrowly campanulate (vs. broadly conical), and corolla mouth $13-18 \mathrm{~mm}$ in diam. (vs. $18-28 \mathrm{~mm}$ ).

Woody vines; young branchlets somewhat flattened, terete to subterete with age, minutely and sparsely puberulent to glabrate, interpetiolar colleters $1-1.5 \mathrm{~mm}$ in young stems, conspicuous, fully developed in old stems, $6-13 \mathrm{~mm}$, latex white. Leaves opposite; petioles 2-5 mm; leaf blades 5.5-14 × 3-6.6 $\mathrm{cm}$, elliptic, broadly elliptic to obovate-elliptic, the apex acute to abruptly and shortly acuminate, rarely retuse, the base cordate, with 8-12 colleters grouped at the base of the leaf blade adaxially, firmly membranaceous, minutely puberulent to glabrescent adaxially, sparsely to densely puberulent abaxially, conspicuously bullate, without domatia, sometimes slightly revolute, secondary and tertiary veins conspicuously impressed on both surfaces. 
Inflorescence axillary, rarely subterminal, longer than the subtending leaves, minutely and sparsely puberulent, (4-)7-15-flowered, peduncle 4-10 cm, pedicels 9-16 mm; bracts 2-3.2 × 1-1.5 mm, narrowly ovate, scarious, early deciduous; sepals 5.3-8 × 1.6$2.3 \mathrm{~mm}$, narrowly ovate, equal to subequal, the apex acuminate, conspicuously reflexed, scarious, glabrous on the adaxial surface, colleters in alternate groups of 2-3, irregularly lacerate apically; corolla narrowly infundibuliform, pink, the lobes base and throat dark pink, glabrous without, the tube straight, not gibbous, lower part 1.2-1.6 cm $\times 2-2.3 \mathrm{~mm}$, upper part $11-19 \mathrm{~mm}$, narrowly campanulate, expanding abruptly near the mouth, $13-18 \mathrm{~mm}$ of diam. at the mouth, the apex of the floral bud acuminate; lobes 23-38 $\times 18-32 \mathrm{~mm}$, obovate, spreading; stamens inserted at the base of the upper part of the corolla tube, anthers 6.5-7.2 mm, dorsally glabrous, the base auriculate, with the auricles rounded; style-head 2.2$2.5 \mathrm{~mm}$; ovary 1.2-1.6 mm, glabrous, nectaries 2, ca. half or less of the ovary length. Follicles 16-18 $\times 0.2$ $0.4 \mathrm{~cm}$, glabrous, free, sometimes united at the tips, glabrous, continuous; seeds 6-7 mm, minutely and densely puberulent, coma not seen.

Etymology. The name refers to the bullate leaf blade.

Distribution and habitat. Endemic to Brazil (Bahia and Minas Gerais states), growing on inselbergs and rocky formations at 450-1400 m a.s.l. (Fig. 2). Flowering from October to May. Fruiting in April, May, and July.

Observations. The following combination of characters distinguish $M$. bullata: branchlets with conspicuous interpetiolar colleters (coriaceous and up to $13 \mathrm{~mm}$ long in old stems), bullate leaf blade, inflorescence surpassing the subtending leaves, corolla narrowly infundibuliform, with the tube $13-18 \mathrm{~mm}$ in diam. at the mouth, and follicles $16-18 \mathrm{~mm}$ long. Mandevilla bullata is morphologically similar to $M$. splendens, a species restricted to inselbergs or granitic outcrops in Rio de Janeiro and Minas Gerais. Both species have in common conspicuous interpetiolar colleters, shortpetiolate leaves, and inflorescences surpassing the subtending leaves. Mandevilla bullata differs by its sepals 5.3-8 mm long (vs. 8-14 mm), upper part of the corolla tube 11-19 $\mathrm{mm}$ long (vs. 18-28 mm), narrowly campanulate (vs. broadly conical), and corolla mouth $13-18 \mathrm{~mm}$ in diam. (vs. $18-28 \mathrm{~mm}$ ).

Conspicuous interpetiolar colleters are uncommon in neotropical apocynoids. This character has been reported in Mandevilla, Mesechites, and Odontadenia (Morales, 1999; 2006; Woodson, 1933). In Mandevilla, interpetiolar colleters are usually inconspicuous, but in a few species, these are fully developed in old stems, resembling claws [e.g., M. martiana (Stadelm.) Woodson, M. moricandiana (A. DC.) Woodson, M. splendens, M. surinamensis (Pulle) Woodson, M. veraguasensis (Seem.) Hemsl.]. Mandevilla bullata is separated from these species by its bullate leaves.

Mandevilla bullata is listed as Endangered (EN), based on criteria $2 \mathrm{ab}$ (i, ii, iii) of the IUCN Red List. This species has an EOO of $39.5 \mathrm{~km}^{2}$ and of AOO of $36.0 \mathrm{~km}^{2}$. Although the AOO and EOO estimates exceed those required for endangered status, the restricted habitat (inselbergs) and few populations known (mostly outside of protected areas), justified the classification as Endangered.

\section{Specimens examined.}

BRAZIL. Bahia. Mun Itamaranjú, Serra da Itamaranjú, Morro Pesçoso, ca. $15 \mathrm{~km}$ da entrada da cidade, 11-II-2007 (fl), Amorin et al. 6908 (CEPEC, HUEFS); Monte Pescoso, 12-I-2009 (fl), Silva \& Morales 18149 (CR). Mun. Serra dos Aimorés, 4 $\mathrm{km}$ de Lajeado da estrada para Nanuque, 10-IV-1996 (fl, fr), Martinelli et al. 14845 (RB). Mun. Caetité, Brejinho das Ametistas, área de Bahia Mineração, IV-2008 (fl, fr), Mendes et al. 247 (BHCB). Goiás. Mun. Alto Paraíso, $6 \mathrm{~km} \mathrm{~S}$ de Alto Paraíso, 4-XII1988 (fl), Kral \& Wanderley 75872 (CR). Minas Gerais. Mun. Pedra Azul, 27-III-1966 (fl), Duarte 9663 (HB, Z); Pedra Azul, Pedra da Conceição, 20IV-1964 (fl), Fromm \& Trinta 1830 (HB, M, NY), Trinta \& Fromm 754 (CR, HB, NY, R, Z); Pedra Azul, estrada a Jequitinhonha, 20-X-1988 (fl), Harley et al. 25224 (K, SPF); Pedra Azul, 16-X-1981 (fl), Hatschbach 44287 (C, CR, HBG, MBM, MO, US, Z). Mun. Medina, Morro Agudo, 19-II-1989 (fl), Hatschbach \& Cordeiro 52709 (MBM, WAG). Mun. Santa María do Salto, $6 \mathrm{~km}$ de Santa María do Salto camino a Talisma, 25-III-2010 (fl), Kollmann et al. 11908 (CR, MBML); 35 km O de Joaíma, 14-XI1959 (fl), Magalhâes 15672 (CR, MO). 


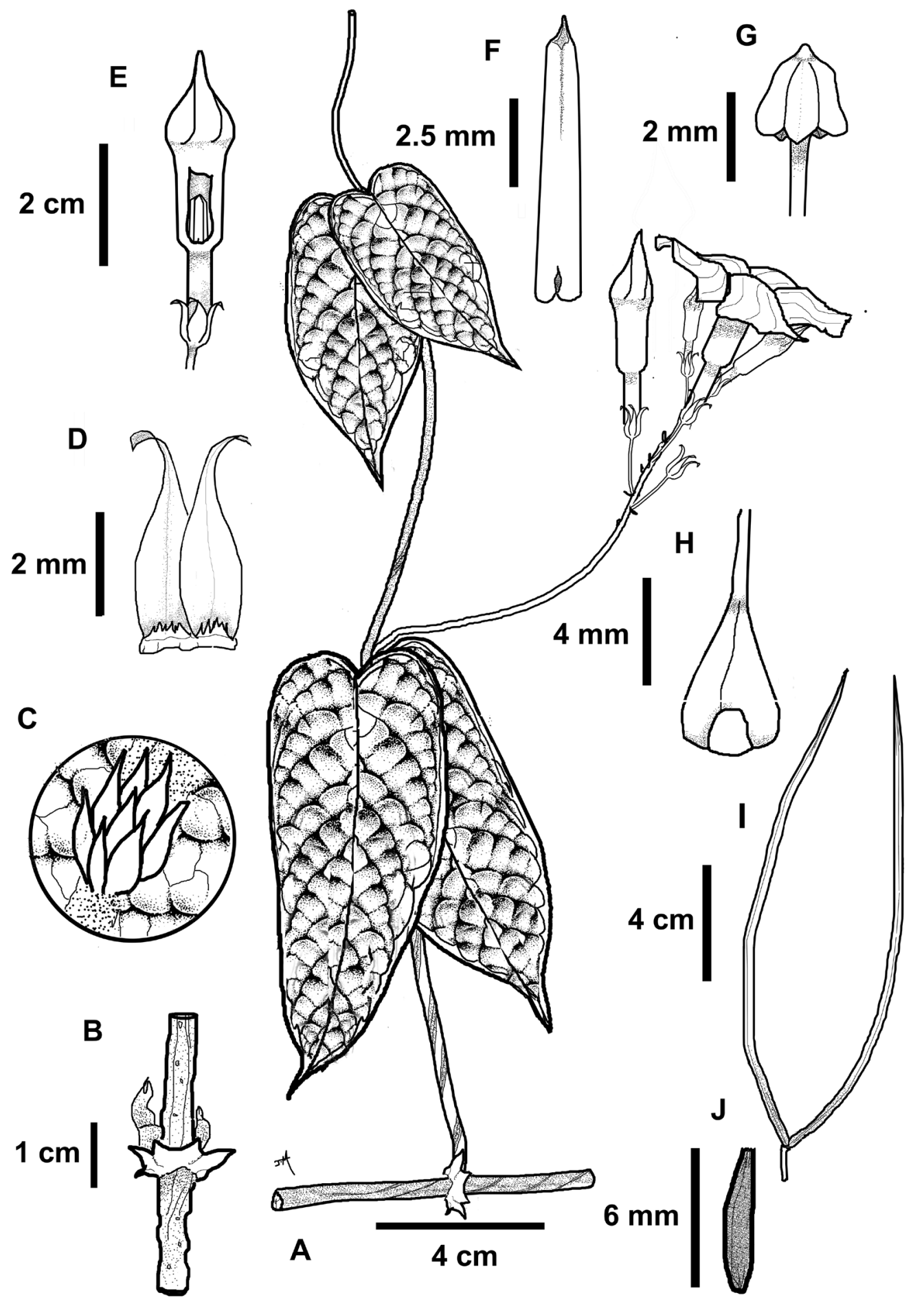

Fig. 1. Mandevilla bullata. A, flowering branch. B, detail of the interpetiolar colleters. C, detail of the adaxial base of leaf blade, showing the arrangement of the colleters. D, adaxial view of two sepals, showing the colleters at the base. E, corolla tube partially open, showing the position of the anthers. F, anther, dorsal view. G, style-head. H, ovary and nectaries. I, follicles. J, seed (without coma). A-G from Roque et al. 15044 (CR); I-J from Martinelli et al. 14845 (RB). 


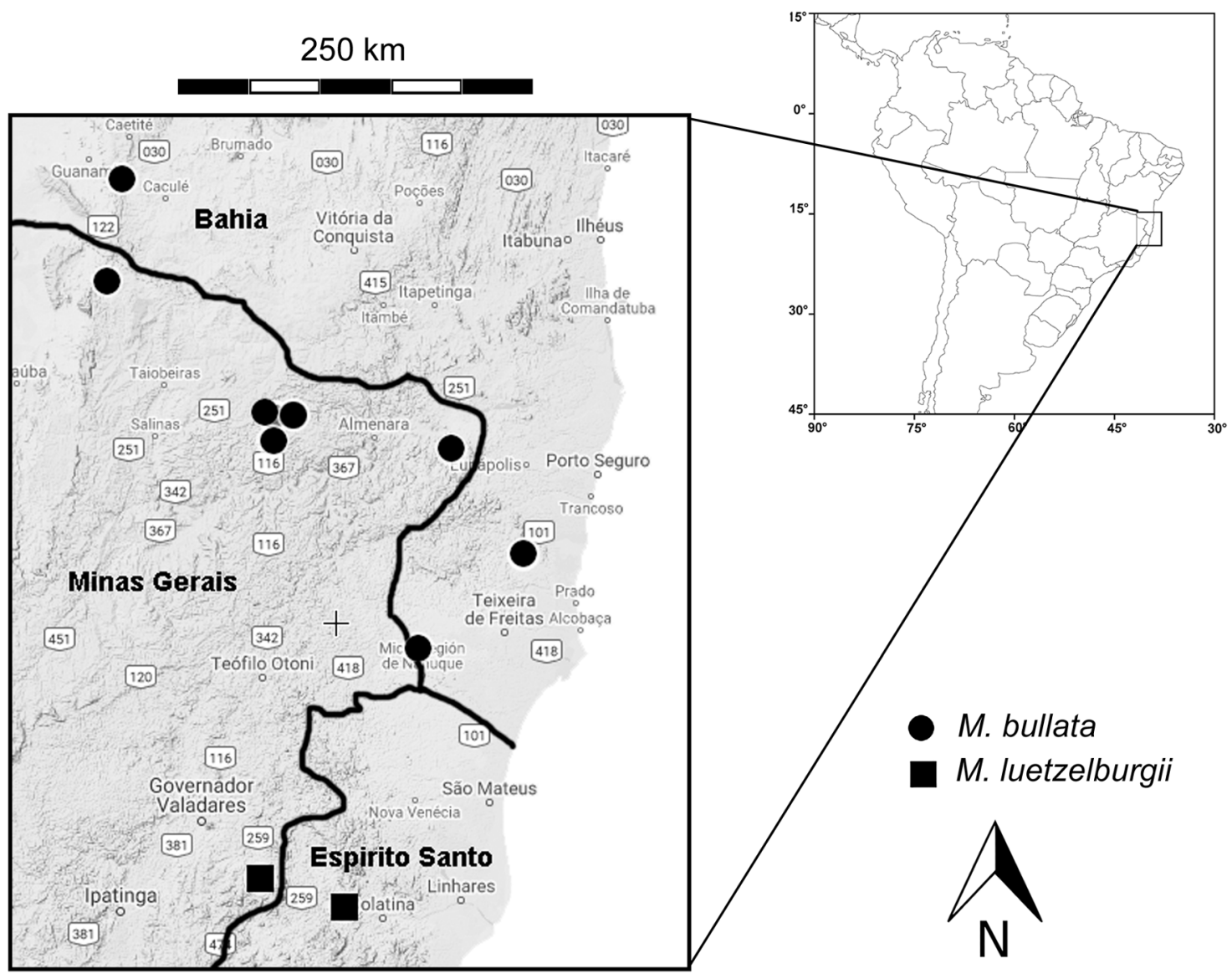

Fig. 2. Distribution map of M. bullata and M. luetzelburgii.

Mandevilla luetzelburgii (Ross \& Markgr.) Woodson, Ann. Missouri Bot. Gard. 20: 698. 1933. Dipladenia luetzelburgii Ross \& Markgr., Notizbl. Bot. Gart. Berlin-Dahlem 9: 396, f. 8. 1925. TYPE: Brazil, Espírito Santo, Serra da Pindoba, Rio Doce, II-1917 (fl), $P$. Lützelburg 7155 (lectotype M [cb M 0210882]! here designated; isolectotypes, B [destroyed, photo F neg 4503]!, M [ cb M 0210883]!). Figs. 3 and 4 E-H.

Woody vines; young branchlets somewhat flattened, terete to subterete with age, minutely and sparsely puberulent to glabrate, interpetiolar colleters $1-1.5 \mathrm{~mm}$ in young stems, conspicuous, fully developed in old stems, 6-11 $\mathrm{mm}$, latex white. Leaves opposite; petioles 1-3 mm; leaf blades $5-7 \times 2-2.8 \mathrm{~cm}$, elliptic to ovate-elliptic, the apex abruptly and shortly acuminate, the base obtuse to subcordate, with 8-12 colleters grouped at the base of the leaf blade adaxially, subcoriaceous, minutely puberulent to glabrescent adaxially, densely to moderately puberulent abaxially, not bullate, without domatia, revolute, secondary veins slightly impressed on both surfaces, tertiary veins scarcely visible abaxially, inconspicuous adaxially. Inflorescence axillary, longer than the subtending leaves, minutely and sparsely puberulent, 6-12 flowered, peduncle 0.9$1.4 \mathrm{~cm}$, pedicels $5-8 \mathrm{~mm}$; bracts $2-3.2 \times 1-1.5$ $\mathrm{mm}$, narrowly ovate, scarious, early deciduous; sepals 4-5 × 2.3-2.5 mm, narrowly ovate, equal to subequal, the apex acuminate, sometimes somewhat reflexed, scarious, minutely puberulent, 
on the adaxial surface, colleters in alternate groups of 4-6, entire; corolla infundibuliform, white to whitish-pink, the lobes base slightly pink, throat yellow, inconspicuously puberulent without, the tube straight, not gibbous, lower part 1.2-1.6 cm $\times$ 1.6-2 $\mathrm{mm}$, the upper part 12-14 $\mathrm{mm}$, conical, 9-10 $\mathrm{mm}$ in diam. at the mouth, the apex of the floral bud acute; lobes 19-22 × 19-24 mm, obovate, spreading; stamens inserted at the base of the upper part of the corolla tube, anthers 7.8-8.1 mm, dorsally glabrous, the base auriculate, with the auricles rounded; style-head 2.2-2.5 mm; ovary $1.8-2 \mathrm{~mm}$, glabrous, nectaries 5 , ca $1 / 2-1 / 3$ as long as the ovary length. Follicles $13-15 \times 0.2-0.4 \mathrm{~cm}$, glabrous, free, sometimes united at the tips, glabrous, continuous; seeds 6-7 $\mathrm{mm}$, minutely and densely puberulent, coma $1.2-1.4 \mathrm{~cm}$.

Distribution and habitat. Endemic to Brazil (Espirito Santo and Minas Gerais states), growing on inselbergs, at 500-900 $\mathrm{m}$ a.s.l. (Fig. 2). Flowering and fruiting in January to February.

Observations. Mandevilla luetzelburgii resembles M. splendens, but it is differentiated by its leaf blades $5-7 \times 2-2.8 \mathrm{~cm}($ vs. $8-18 \times 3.5-10 \mathrm{~cm})$, sepals $4-5 \mathrm{~mm}$ long (vs. 8-14 $\mathrm{mm}$ ), and upper part of the corolla tube conical, 12-14 mm long (vs. campanulate, $18-28 \mathrm{~mm}$ long). The sheet $\mathrm{M} \mathrm{cb}$ 0210882 is selected as the lectotype of Dipladenia luetzelburgii. The two sheets available at $\mathrm{M}$ are in poor condition, but this specimen ( $\mathrm{M} \mathrm{cb}$ 0210882) has flowers and fruits, whereas the second sheet (M cb 0210883) does not has flowers.

Inselbergs and quartzite outcrops are a hotspot of endemism for Mandevilla in Colombia, Venezuela and Brazil. Inselbergs are common in some states of Brazil (e.g., Espirito Santo, Minas Gerais, Pernambuco, Rio de Janeiro), whereas in Colombia and Venezuela are uncommon and restricted to the Amazon basin. Quartzite outcrops are common in the Guyana shield, but in Brazil are restricted to mountains formations in Bahia, Goiás, and Minas Gerais (e.g, Serra do Espinhaço, Chapada Diamantina) (Alves et al., 2007). For more than 100 years, $M$. luetzelburgii was known only from two collections. Other poorly collected Mandevilla in Brazil restricted to rocky outcrops and inselbergs include M. catimbauensis SouzaSilva, Rapini \& J.F. Morales (Pernambuco), M. crassinoda (Gardner) Woodson (Rio de Janeiro), M. harleyi M.F. Sales, Kin.-Gouv. \& A.O. Simões (Minas Gerais), M. rubra Markgr. ex M.F. Sales, Kin.-Gouv. \& A.O. Simões (Minas Gerais), and M. semirii M.F. Sales, Kin.-Gouv. \& A.O. Simões (Minas Gerais) (Sales et al., 2006; Souza-Silva et al., 2010). The distribution of the populations among inselbergs from the same locality is variable. For example, in seven inselbergs around the type locality of $M$. harleyi, plants were found in only two, whereas in five inselbergs around type locality of $M$. luetzelburgii no additional plants were found. The conditions which regulate the distribution and population size are unknown, which are poorly understood for many species of neotropical apocynoids (Morales, 2018).

Mandevilla bullata, M. luetzelburgii, and $M$. splendens are named here as the "M. splendens complex". An additional undescribed species restricted to limestone formations in Goiás also belongs to this complex. These species are characterized by its sessile or subsessile leaves, leaf blade with the colleters restricted to the base of the midrib adaxially, and infundibuliform corolla. They are endemic to inselbergs or rocky outcrops in southern Bahia, Espirito Santo, eastern Minas Gerais, Goiás, and Rio de Janeiro. A key to separate these species is provided. Some diagnostic morphological characters are illustrated in figure 4. The undescribed species from Goiás is included in the key as "Mandevilla sp. A".

Mandevilla luetzelburgii is Critically Endangered (CR) based on criteria B1ab (i, ii, iii) + 2ab (i, ii, iii). Only two populations are known (AOO: 8 $\mathrm{km}^{2}$ ), both restricted to inselbergs, which represent a small and critical area of distribution. Additional fieldwork might reveal more populations in different localities, but based on its current distribution, $M$. luetzelburgii should be considered Critically Endangered.

\section{Specimens examined.}

BRAZIL. Minas Gerais. Mun. Conselheiro Penha, Conselheiro Penha, chapada do João Pinto, 19IV-2018 (fl), Kollmann \& Cipriano 13532 (MBML). 


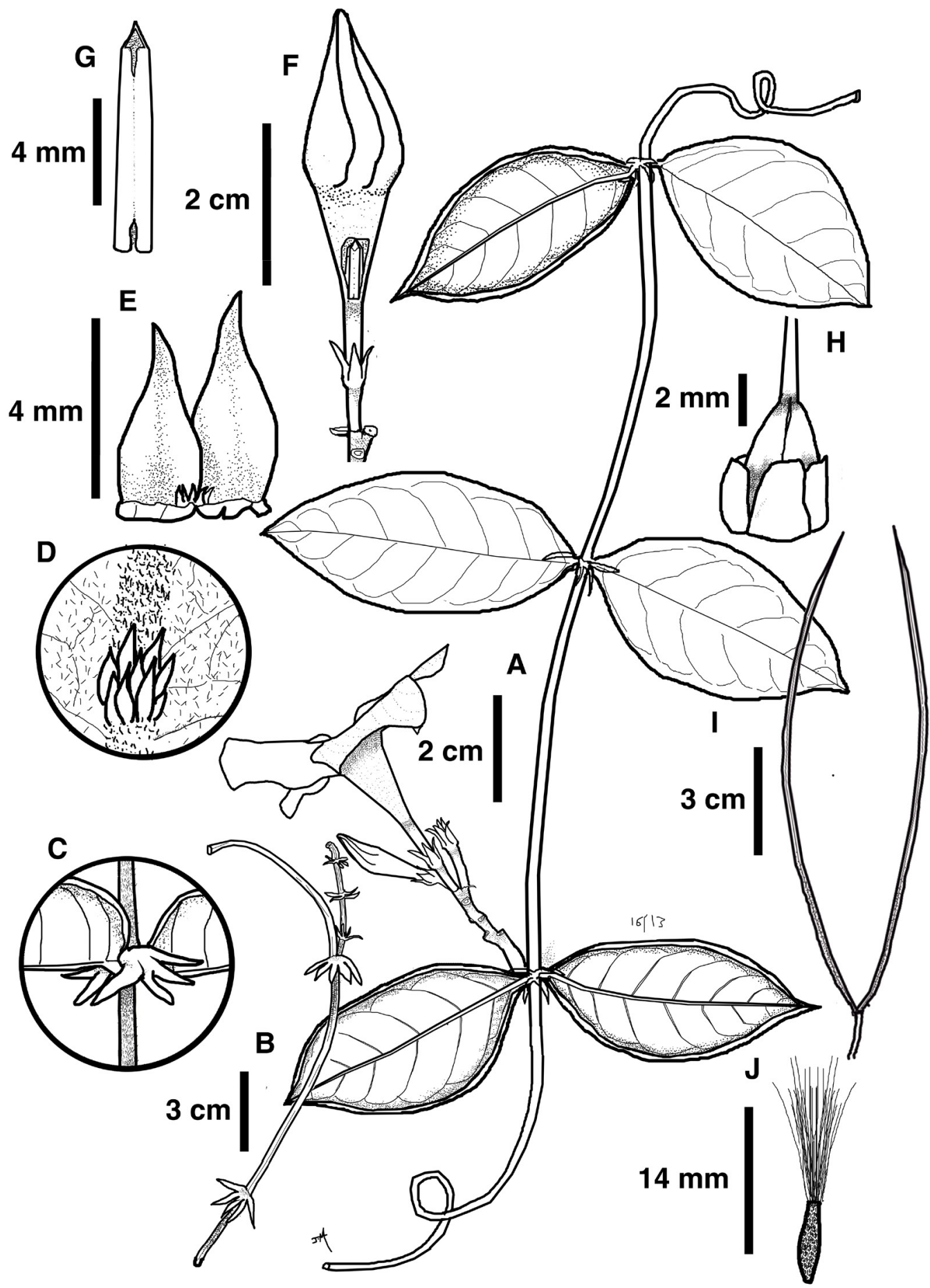

Fig. 3. Mandevilla luetzelburgii. A, flowering branch. B, leafless stem showing the interpetiolar colleters. C, details of the interpetiolar colleters. D, detail of the adaxial base of leaf blade, showing the arrangement of the colleters. E, adaxial view of two sepals, showing the colleters at the base. F, calyx, pedicel, bract, and corolla tube partially open, showing the position of the anthers. G, anther, dorsal view. H, ovary and nectaries. I, follicles. J, seed. A, C-H from Kollmann \& Cipriano 13532 (MBML); B, I, J from Lützelburg 7155 (M). 


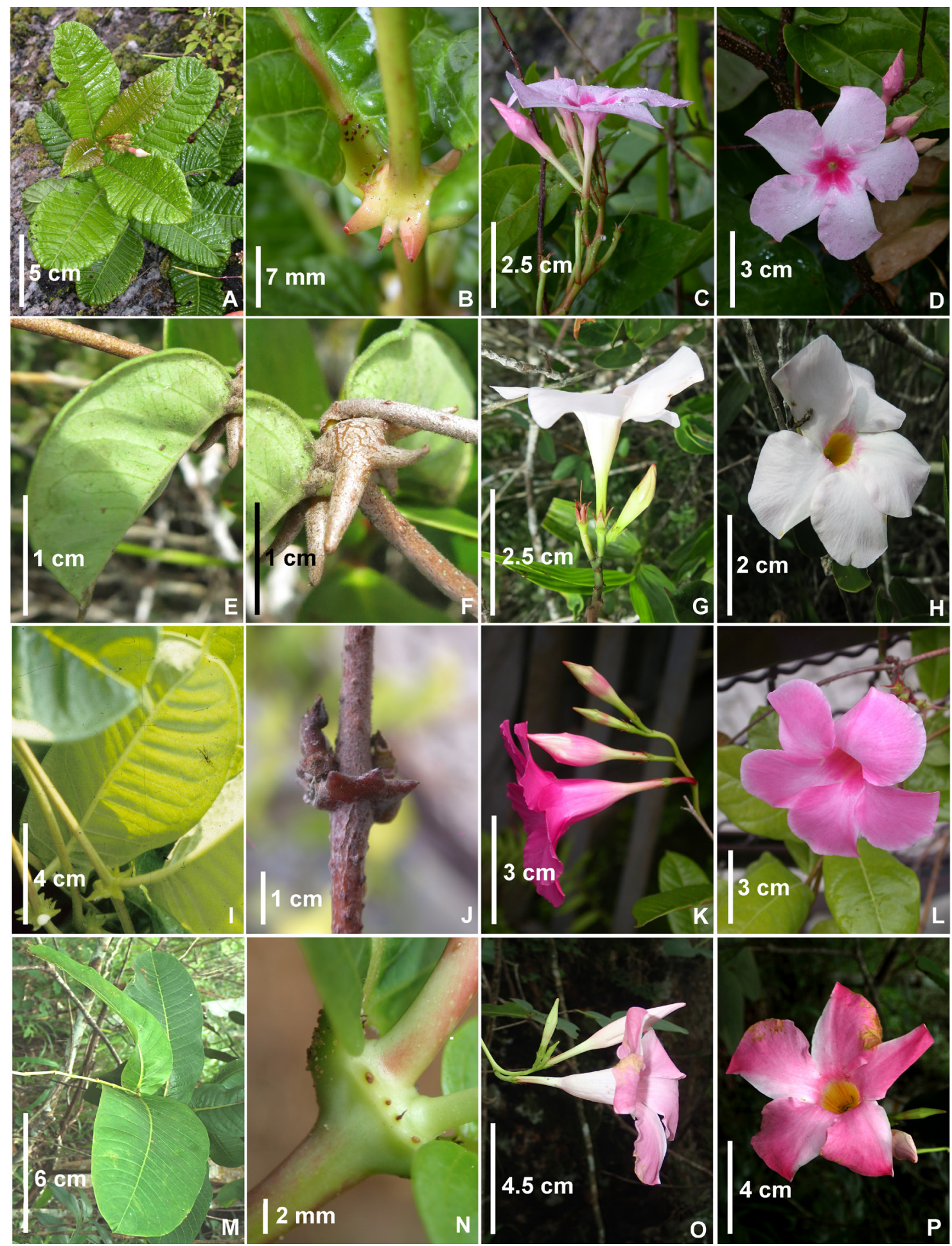

Fig. 4. Morphological characters in the Mandevilla splendens complex (A-D, M. bullata; E-H, M. luetzelburgii; I-L, M. splendens; M-P, M. sp. A). A, E, I, M, leaves. B, F, J, N, intrapetiolar colleters. C, G, K, O, inflorescence. D, H, L, P, corolla. Color version at http://www.ojs.darwin.edu.ar/index.php/darwiniana/article/view/903/1192 


\section{Key to the species of the $M$. splendens complex}

1. Leaf blade conspicuously bullate M. bullata

1. Leaf blade not bullate 2

2(1). Tertiary veins scarcely visible abaxially; corolla mouth 9-10 $\mathrm{mm}$ in diam.; nectaries five M. luetzelburgii

2. Tertiary veins conspicuous abaxially; corolla mouth $13-28 \mathrm{~mm}$ in diam.; nectaries two 3

3(2). Leaf blade glabrous; sepals 6-7.5 mm long; upper part of the corolla tube campanulate; corolla lobes 38-41 mm long; interpetiolar colleters inconspicuous, up to $0.3 \mathrm{~mm}$ long; limestone formations in Goiás M. $\operatorname{sp} A$.

3. Leaf blades tomentulose; sepals 9-14 mm long; upper part of the corolla tube broadly conical; corolla lobes 25-34 mm long.; interpetiolar colleters conspicuous, up to $10 \mathrm{~mm}$ long; granitic outcrops or inselbergs in Rio de Janeiro

M. splendens

\section{ACKNOWLEDGMENTS}

Financial or logistical support was partially provided by the Deutscher Akademischer Austauschdienst (Germany), and the Museu de Biologia Mello Leitão (INMA) (Brazil). Ludovic Kollmann thanks the "Instituto Nacional da Mata Atlântica (INMA)". We thank the curators of the following herbaria for allowing the study of their collections: B, BHCB, CEPEC, CR, HB, HUEFS, K, M, MBM, MBML, MO, NY, R, RB, SPF, UBT, US, WAG, and Z.

\section{REFERENCES}

Allen, C. K.; D. Rogers \& L. Nevling. 1965. Robert Everard Woodson, Jr. (1904-1963) Brittonia 17: 1-11.

Alves, R. J. V.; L. Cardin \& M. S. Kropf. 2007. Angiosperm disjunction "Campos rupestres - restingas": a re-evaluation. Acta Botanica Brasilica 21: 675-685. DOI: http://doi. org/10.1590/S0102-33062007000300014

Bachman, S.; J. Moat; A. W. Hill; J. de la Torre \& B. Scott. 2011. Supporting Red List Threat assessments with GeoCAT: geospatial conservation assessment tool. Zookeys 150: 117126. DOI: https://doi.org/10.3897/zookeys.150.2109

Barthlott, W. \& S. Porembski. 2000. Vascular plants on inselbergs: systematic overview. In S. Porembski \& W. Barthlott (eds.), Inselbergs - biotic diversity of isolated rock outcrops in tropical and temperate regions. Ecological Studies 146, pp. 103-116.

Eckardt, T. 1965. Zum Gedenken an den 200. Geburtstag von Carl Ludwig Willdenow *22.8.1765-†10.7.1812. Willdenowia 4: 1-21.

Hiepko, P. 1987. The collections of the Botanical Museum Berlin-Dahlem (B) and their history. Englera 7: 219-252.
IUCN. 2017. The IUCN Red List of Threatened Species. Version 2014.3. [http://www.iucnredlist.org].

Jacobi, C. M.; F. F. Carmo; R. Vincent \& J. R. Stehmann. 2007. Plant communities on ironstone outcrops: a diverse and endangered Brazilian ecosystem. Biodiversity Conservation 16: 2185-2200. DOI: https://doi.org/10.1007/s10531-007-9156-8

Juárez, P.; R. Flores \& M. A. Blanco. 2018. Bauhinia proboscidea (Fabaceae: Cercidoideae), a new species from Costa Rica and Panama, with notes on B. beguinotii, $B$. gorgonae and B. pansamalana. Phytotaxa 361: 25-40. DOI: https://doi.org/10.11646/phytotaxa.361.1.2

Judd, W. S.; C. S. Campbell; E. A. Kellogg; P. F. Stevens \& M. J. Donoghue. 2016. Plant systematics: A phylogenetic approach. 4th Ed. Sinauer Associates, Sunderland.

Merrill, E. D. 1943. Destruction of the Berlin Herbarium. Science 98: 490-491.

Morales, J. F. 1999. A synopsis of the genus Odontadenia. Series of revisions of Apocynaceae XLV. Bulletin du Jardin Botanique National de Belgique 67: 381-477. DOI: https:// doi.org/10.2307/3668437

Morales, J. F. 2005. Estudios en las Apocynaceae Neotropicales $\mathrm{X}$ : definición de la verdadera identidad de M. leptophylla (A. DC.) K. Schum., con la descripción de dos nuevas especies y una nueva combinación de Mandevilla (Apocynoideae, Mesechiteae) para Sur América. Sida 21: 1535-1548.

Morales, J. F. 2006. Estudios en las Apocynaceae Neotropicales XXVI: una monografía del género Mesechites (Apocynoideae, Mesechiteae). Candollea 61: 215-277.

Morales, J. F. 2018. Studies in Neotropical Apocynaceae LIV: a synopsis of Asketanthera. Candollea 73: 7-17. DOI: https:// doi.org/10.15553/c2018v731a2

Morales, J. F. \& A. Fuentes. 2004. Estudios en las Apocynaceae Neotropicales VIII: nuevas especies de Mandevilla para Perú y Bolivia, con notas sobre la morfología floral en corolas infundibuliformes. Candollea 59: 167-174. 
Morales, J. F. \& L. J. C. Kollmann. 2020. Increasing the known floristic diversity of Brazilian inselbergs: two new species of Mandevilla (Apocynaceae) from Espírito Santo. Acta Botanica Brasilica 34: 107-116. DOI: http://dx.doi. org/10.1590/0102-33062019abb0241

Morales, J. F. \& I. L. Morais. 2020. Studies in the Neotropical Apocynaceae LV: A New Mandevilla from Bahia, Brazil, with notes on the diversity of the genus. Systematic Botany 45: 183-189. DOI: https://doi.org/10.1600/03636 4420X15801369352450

Morales, J. F.; M. E. Endress \& S. Liede-Schumann. 2017. Systematics of Prestonia (Apocynaceae: Apocynoids: Echiteae) 80 Years after Woodson. Annals of the Missouri Botanical Garden 102: 520-541. DOI: https://doi. org/10.3417/D-17-00002A

Morales, J. F.; M. E. Endress; I. L. Morais \& P. Renon. 2020. Mandevilla (Apocynaceae) in the state of Goiás and Distrito Federal, Brazil. Submitted to Willdenowia.

Porembski, S. 2007. Tropical inselbergs: habitat types, adaptive strategies and diversity patterns. Revista Brasileira de Botanica 30: 579-586. DOI: https://doi.org/10.1590/S010084042007000400004

Porembski S. \& W. Barthlott. 2000. Granitic and gneissic outcrops (inselbergs) as centers of diversity for desiccationtolerant vascular plants. Plant Ecology 151: 19-28. DOI: https://doi.org/10.1023/A:1026565817218

Porembski, S.; W. Barthlott; S. Dorrstock \& N. Biedinger. 1994. Vegetation of rock outcrops in Guinea: Granite inselbergs, Sandstone table mountains and ferricretes - Remarks on species numbers and endemism. Flora 189: 315-326. DOI: https://doi.org/10.1016/S0367-2530(17)30612-6

Porembski S.; G. Martinelli; R. Ohlemüller \& W. Barthlott. 1998. Diversity and ecology of saxicolous vegetation mats on Inselbergs in the Brazilian Atlantic rainforest. Diversity and Distributions 4: 107-119. DOI: https://doi.org/10.1046/ j.1365-2699.1998.00013.x

Poppendieck, H. 1990. Hamburg, Africa and Botany. Mitteilungen aus dem Staatsinstitut für Allgemeine Botanik in Hamburg 23a: 11-22.
Radford, A. E.; W. E. Dickison; J. R. Massey \& C. R. Bell. 1974. Vascular Plant Systematics. Harper \& Row, Publishers, New York, Evanston, San Francisco, London.

Ribeiro, K. T.; B. M. O. Medina \& F. R. Scarano. 2007. Species composition and biogeographic relations of the rock outcrop flora on the high plateau of Itatiaia, SE-Brazil. Revista Brasileira de Botanica 30: 623-639. DOI: https://doi. org/10.1590/S0100-84042007000400008

Sales, M. F. 1993. Estudos taxonômicos de Mandevilla Lindley subgênero Mandevilla (Apocynaceae) no Brasil. Ph.D. diss., Universidad Estatal de Campinas.

Sales M. F.; L. S. Kinoshita \& A. O. Simões. 2006. Eight new species of Mandevilla Lindley (Apocynaceae, Apocynoideae) from Brazil. Novon 16: 112-128. DOI: https://doi.org/10.3417/1055-3177(2006)16[112:ENSOML ]2.0.CO;2

Simões, A. O.; M. Endress; T. van der Niet; L. S. Kinoshita \& E. Conti. 2006. Is Mandevilla (Apocynaceae, Mesechiteae) monophyletic? Evidence from five plastid DNA loci and morphology. Annals of the Missouri Botanical Garden 93: 565-591. DOI: https://doi.org/10.3417/00266493(2006)93[565:IMAMME]2.0.CO;2

Souza-Silva R. F.; A. Rapini \& J. F. Morales. 2010. Mandevilla catimbauensis (Apocynaceae), a new species from the semiarid, Pernambuco, Brazil. Edinburgh Journal of Botany 67: 1-5. DOI: https://doi.org/10.1017/S0960428609990230

Thiers, B. [permanently updated, accessed 2020]. Index Herbariorum: a global directory of public herbaria and associated staff. New York Botanical Garden's Virtual Herbarium, http://sweetgum.nybg.org/ih/

Woodson, R. E. 1933. Studies in the Apocynaceae IV. The American genera of Echitoideae. Annals of the Missouri Botanical Garden 20: 605-790.

Woodson, R. E. 1935. Studies in the Apocynaceae IV. The American genera of Echitoideae. Annals of the Missouri Botanical Garden 22: 153-306.

Woodson, R. E. 1936. Studies in the Apocynaceae IV. The American genera of Echitoideae. Annals of the Missouri Botanical Garden 23: 169-438. 